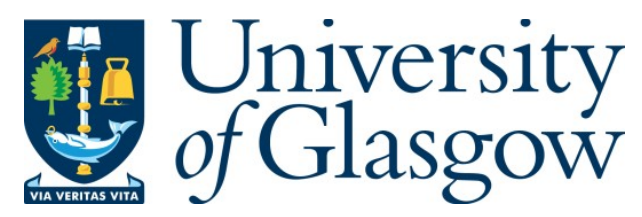

Boussebaa, M. (2015) Professional service firms, globalisation and the new imperialism. Accounting, Auditing and Accountability Journal, 28(8), pp. 12171233.

There may be differences between this version and the published version. You are advised to consult the publisher's version if you wish to cite from it.

http://eprints.gla.ac.uk/122733/

Deposited on: 22 August 2016

Enlighten - Research publications by members of the University of Glasgow http://eprints.gla.ac.uk 


\title{
Professional service firms, globalisation and the new imperialism
}

\author{
Mehdi Boussebaa
}

University of Bath

m.boussebaa@bath.ac.uk

\author{
Accounting, Auditing \& Accountability Journal
}

\section{Structured Abstract}

Purpose - This paper draws on insights from critical accounting research to ground the globalisation of professional service firms more firmly in the history and actuality of imperialism. In so doing, the paper also helps in forging a stronger connection between accounting scholarship and interdisciplinary professions-focused debates in the wider field of management and organisation studies (MOS).

Design/methodology/approach - This is a desk based study of existing literature on the globalisation of professional service firms analysed through the lens of imperialism via an exploration of relevant research on the accounting profession.

Findings - The analysis reveals rich insights into the workings and impact of imperialism that can usefully be drawn on to better inform our understanding of globalisation in the professional services sector and, in particular, to develop existing interdisciplinary debates on the relationship between the professions and institutions at the global level.

Research limitations/implications - The implications of this paper are that the nature of professional services firms (and the professions more generally) is further illuminated, especially their role in (re)producing imperialism in a supposedly post-national and postcolonial world. Further, the paper opens new avenues for future research on the relationship between professional service firms, globalisation and contemporary imperialism.

Originality/value - This is the first attempt to draw together critical accounting studies of globalisation with research on the globalisation of professional service firms in the generalist field of MOS. In so doing, it contributes to a cross-fertilization of the two fields and helps in making the former more central to ongoing debates in the latter. The paper also contributes to the emerging body of postcolonial theorising in MOS by shedding light on the role of professional service firms in (re)producing imperialism in the modern world economy.

\section{Keywords}

Globalisation, Imperialism, Professional service firms, Core-periphery relations 


\section{Introduction}

In the last few decades, global professional service firms (GPSFs) - of which the 'Big Four' accountancies, the leading management consultancies and the 'elite' law firms are prime examples - have emerged as major international corporate players. They have offices dotted all around the world and are often more internationalised than the Fortune Global 500 companies which they serve (Suddaby, Cooper and Greenwood, 2007). Importantly, they play a major part in the global expansion and management of capitalism. They, for instance, contribute significantly to spreading 'best' management practices around the world (Kipping, 1999; McKenna, 2006); to setting 'global' accounting standards (Botzem, 2014); and to establishing universal corporate laws (Halliday and Carruthers, 2009). GPSFs also offer specialised services that are crucial for major multinational corporations in running their geographically dispersed operations (Sassen, 2001).

This development in the world of business has attracted increasing scholarly attention in the field of management and organisation studies (MOS) in the last decade (see e.g. contributions in Empson, Muzio, Broschak and Hinings, 2015). In particular, a growing body of sociologically-oriented research informed primarily by institutional theory has appeared in recent years. This has shed light on how national contexts shape and constrain the worldwide strategies, capabilities and activities of GPSFs (e.g. Morgan, Sturdy and Quack, 2006; Muzio and Faulconbridge, 2013). It has also begun to explore the ways in which GPSFs (and the professions more generally) are affected by, and constitutive of, an emergent 'transnational' institutional environment (e.g. Morgan, 2006; Spence, Dambrin, Carter, Husillos and Archel, in press). An initial attempt has also been made to bring the notion of imperialism into the discussion as a means of taking into account global power relations in the development of GPSFs (Boussebaa, Morgan and Sturdy, 2012).

In this paper, I aim to probe more deeply into the relationship between GPSFs and imperialism in the contemporary period. To this end, I tap into a rich body of critical research on globalisation conducted in the specialist field of accounting and published in leading journals such as Accounting, Organizations \& Society, Critical Perspectives on Accounting and the Accounting, Auditing \& Accountability Journal. Starting with the seminal work of Johnson (1973), this research has long established that the globalisation of the accounting profession has been bound up with imperialism (e.g. Annisette, 2000; Dwyer and Roberts, 2004; Kamla, Gallhofer and Haslam, 2012); yet such work is not always well recognised 
outside of the accounting field and rarely drawn upon to conceptualise and approach globalisation in other professional jurisdictions. At the same time, accounting scholars seldom engage with the interdisciplinary debate on globalisation in the generalist field of MOS when conducting their own analyses (cf. Brock, Leblebici and Muzio, 2014). In this paper, therefore, I aim to advance professions-focused MOS research on globalisation through an analysis of relevant accounting studies whilst at the same time helping to connect the latter with discussions being held in the former. In so doing, I also hope to contribute to developing the emerging body of work concerned with imperialism in the MOS field (e.g. Frenkel, 2008; Jack, Westwood, Srinivas and Sardar, 2011; Prasad, 2003).

The paper proceeds as follows. I first review the literature on the international expansion and organisation of GPSFs, highlighting a growing interest among scholars in understanding these firms as institutional agents in the globalisation process. I also highlight recent calls for research into the link between GPSFs and imperialism in the modern world economy. I then draw selectively on specialist studies of imperialism in the social sciences to develop a framework with which analyse globalisation as a process of imperialism. Next, I draw on the accounting literature as a source of empirical data to illustrate some of the imperial dynamics involved in the work of GPSFs. This leads me to argue that the globalisation of professional service firms is intimately related to Western imperialism - past and present - and that future studies would do well to recognize this link and incorporate dynamics of empire into their analyses. I conclude by highlighting a few areas for future investigation.

\section{From national to transnational dynamics - and beyond}

In the last two decades or so, a growing body of research in the field of MOS has examined the meaning and implications of 'globalisation' within the professional services sector. Following an initial phase of research conducted from organizational change and international management perspectives (e.g. Aharoni, 1996; Ferner et al., 1995; Fenton and Pettigrew, 2003; see also Greenwood et al., 2010), scholars have gradually turned attention to issues of institutional embeddedness and change. One key contribution here has been to show how national institutional contexts shape and constrain efforts by GPSFs to organise professionals and serve clients across nations (e.g. Boussebaa, 2009, 2015; Muzio and Faulconbridge, 2013; Morgan et al., 2006). For instance, using the notion of 'institutional duality' (Kostova and Roth, 2002), Faulconbridge and Muzio (2013) revealed how attempts by English law firms to reproduce their UK model of professional practice in Italy created "conditions of institutional 
illegitimacy" (p. 21) in that context and, as a result, various problems, including "demergers, lawyer exoduses [and] clashes with local regulators" (ibid.). Work such as this has been very useful in revealing the presence of strong national path-dependencies inside GPSFs (see also Morgan and Quack 2006b) and, in so doing, countered the globalisation rhetoric produced by these organisations. It has shown that GPSFs, as in the case of multinational enterprises in other sectors (see e.g. Boussebaa and Morgan, 2008; Ferner, Quintanilla and Varul, 2001), remain deeply rooted in their country of origin and are also significantly influenced by the host national institutional contexts across which they operate.

In parallel with and building on this work, scholars have also sought to approach and understand GPSFs as institutional agents, i.e. as shapers, not just carriers, of institutions (e.g. Boussebaa et al., 2012; Faulconbridge and Muzio, 2012; Morgan, 2006; Morgan and Quack, 2005, 2006; Spence et al., in press). A key argument here has been that GPSFs have put considerable effort into developing 'transnational' organizational structures and processes and, therefore, cannot merely be reduced to 'national' institutional contexts. In managing and delivering many global client projects, GPSFs also create work situations that often require the expertise of cross-national teams, generating in the process practices and identities that are hybrid in nature rather than country-specific (Smets, Morris and Greenwood, 2012). For all these reasons, GPSFs are seen to be gradually developing professional-organisational arrangements that are 'transnational' in scope and substance and, in the process, also giving rise to a 'transnational' field for professional services (see e.g. Suddaby et al., 2007). In paying attention to the 'transnational', there is also recognition that the 'national' dimension does not become irrelevant, that "[n]ational varieties of values and practices do no melt away" (Faulconbridge and Muzio, 2012: 146) and that, therefore, the focus of research should be on processes of co-existence, negotiation, adaptation and hybridisation.

This body of work has greatly advanced our understanding of GPSFs and their role in shaping the world economy, and there is no doubt that it will be developed further through both deeper empirical investigations and more refined conceptual frameworks (e.g. see recent efforts by Faulconbridge and Muzio, 2015, to understand how law firms respond to cross-national institutional complexity). However, it has given very little attention to the link between GPSFs and imperialism, thereby neglecting or downplaying the global relations of domination and inequalities that are (re)produced in the emergent 'transnational' professional services arena. Drawing on research into global management consultancies, Boussebaa et al. (2012) begin to 
show that "the transnational social space of [GPSFs] is structured by power relations that have their roots in the broader international division of labour and history of colonialism and imperialism" (Boussebaa et al., 2012: 481) and call for more detailed research on these processes (see also Boussebaa and Morgan, 2014, 2015; Boussebaa et al., 2014b). Echoing this view, Brock et al. (2014: 10) highlight the study of imperialism as "a key priority" for future research on the societal role and impact of GPSFs. I believe the critical accounting literature has much to offer on the topic and should be brought into the discussion. Before exploring this work, however, it is important to briefly elaborate on the meaning of imperialism and why this concept is relevant in a supposedly post-colonial world.

\section{Imperialism in the modern world economy}

A considerable amount of literature has been produced on the theme of imperialism in the last few decades, spanning fields as diverse as geography (Harvey, 2003), economics (Amin, 1976), literary theory (Said, 1993), sociology (Pieterse, 2004) and political science (Saccarelli and Varadarajan, 2015). A growing number of studies on the topic has also appeared in the field of MOS in recent years (e.g. Frenkel, 2008; Jack, Westwood, Srinivas and Sardar, 2011; Özkazanç-Pan, 2008; see also contributions in Prasad, 2003). Running through this body of work is that imperialism, in one form or another, is not over; that the dissolution of the European empires after the Second World War simply marked the end of a particular phase in the long history of imperialism or perhaps a particular form of imperialism, not imperialism itself.

Indeed, one major effect of the 'old' imperialism of European colonial powers is that it established an enduring hierarchical, core-periphery world order, i.e. one in which a few dominant states located (mostly) in the 'West' formalised a privileged role for themselves and asserted managerial responsibility over weaker nations in the rest of the world (Amin, 1976; Chase-Dunn, 1998; Wallerstein, 2011). Prior to the Second World War, such a world order was characterised by a relatively simple international division of labour in which the 'core' specialised in manufacturing and exporting goods while the 'periphery' - mostly colonies of European empires - served as a source of raw materials and food stuffs for core markets. Following the decolonisation of much of the world, a "new international division of labour" (Frobel et al., 1980) began emerging in the 1960s and 1970s as core nations (now labelled 'developed' or 'advanced' economies) relocated segments of their industrial base to peripheral societies (now called 'developing' or 'emerging' economies). In this new division of labour, 
core-periphery relations are more complex but, generally, the core specialises in skilled (capital/knowledge-intensive) production using highly paid labour and the periphery in unskilled or low-skilled (labour-intensive) production using low wage labour. The result is a continued hierarchical - albeit (arguably) less extremely unequal - world order in which the core bolsters and sustains its dominance and economic growth by opening up new markets and by exporting high-value expertise to, and exploiting low-cost labour in, the periphery.

This new core-periphery hierarchy is reproduced thorough a variety of different state and market mechanisms, with US-led international organizations (e.g. IMF, World Bank) and, in particular, Western multinationals playing a central role (Petras and Veltmeyer, 2007). Here, it is useful to note that the majority of the world's largest and most powerful multinationals are headquartered in former colonialist countries (particularly Britain, France, Germany and The Netherlands) and new imperial nations (e.g. USA). Equally noteworthy is that these organisations are establishing and controlling a growing number of subsidiaries in 'emerging' markets, i.e. countries that were once colonies of the European Empires and that have continued, in many cases, to provide their former imperial masters with labour, markets and materials. Key to sustaining these relations is the 'comprador' class, i.e. that segment of the periphery's elite which is subordinated to foreign capital and whose raison d'être is to act as "a kind of staging-post and direct intermediary for the implantation and reproduction of foreign capital in the countries concerned" (Poulantzas, 1976: 42). In the 'old' imperialism, this function was performed by the colonisers themselves (together with the support of indigenous collaborators) but in the present era, it is mostly played by compradors.

That said, imperialism is not merely an act of economic exploitation; it is also a process of cultural domination. And here postcolonial theory is particularly useful as it emphasises the power of knowledge, discourse and representation in maintaining core-periphery relations (see e.g. Said, 1978, 1993). It points to how imperial power is exercised through fake claims to 'universalism', i.e. by depicting particular local cultural standards as if they were trans-societal norms what are in effect merely 'local' cultural standards. Localisms that do not match such norms are then portrayed as 'backward' and thus in need of reform. Postcolonial theory encourages to view such claims as suspect because they ignore cultural and institutional heterogeneity, and in so doing marginalize local subjectivities and forms of knowledge that do not conform to what is considered to be 'universal'. And in the act of marginalization lies an act of suppression, an expression of power. The professions appear to play a key part in this 
process given their role in universalizing Western (especially US) norms and values. For instance, the work of Dezalay and Garth $(2002,2008,2010)$ shows how Western lawyers, in collaboration with comprador legal professionals in Asia and Latin America, have contributed to constructing and sustaining the new imperialism through the global diffusion of neoliberal economics and a US conception of law.

But where there is power there is also resistance and here postcolonial theory is also very useful in that it conceives of power/resistance as a relation. In particular, Bhabha's notion of 'mimicry' helps us appreciate that the core-periphery encounter is fundamentally ambivalent and mutually constitutive. That is, the 'core' presents itself as the bearer of universality and seeks to transform the 'Other' in its own image, yet at the same time maintains difference, economically and culturally - doing otherwise would in effect delegitimize and bring to an end the social structures perpetuating core-periphery divisions. In this context, the 'periphery', itself a site of much cultural diversity that can never be fully absorbed into the 'core', is led to 'mimic' rather than replicate 'universals', to be "almost the same but not quite" (Bhabha, 1994: 89 ), a process that inevitably produces 'hybridity' rather than sameness. Here, hybridity is not to be viewed in 'neutral' terms as some kind of blending of previously distinct localisms, but as a form of resistance in the sense that its presence continually threatens the purity of universals and frustrates the core's ability to reform the 'Other' - in short, it is an expression of both "enforcement and resistance" (Frenkel, 2008: 933; see also Boussebaa et al., 2014a).

\section{Global accounting firms and the new imperialism}

The accounting literature has, over the last four decades, produced a rich vein of research on the link between the accounting profession and imperialism. Much of this work is historical in nature, concentrating in particular on the role of accounting associations during British imperialism in the late 19th century (e.g. Chau and Poullaos, 2002; Johnson, 1973; Johnson and Caygill, 1971), but a growing body of research focuses on the $20^{\text {th }}$ century (e.g. Annisette, 2000) and recent decades (e.g. Caramanis, 2002; Cooper, Greenwood, Hinings and Brown, 1998; Dwyer and Roberts, 2004; Gallhofer, Haslam and Kamla, 2011; Kamla, Gallhofer and Haslam, 2012). Much can be derived from this work on the link between GPSFs and imperialism in the contemporary world economy. In what follows, I explore such work through a consideration of (1) the emergence of global accounting firms on the back of colonialism; (2) the role of these organisations in (re)producing core-periphery relations today; (3) their efforts 
at universalising an Anglo-American mode of professional practice; and (4) their dependence on collaborative yet resistive local professionals.

\section{Emergence, colonialism and beyond}

One key insight from the accounting literature is that the worldwide expansion of the Western accounting profession and associated emergence of international accounting firms went hand in hand with European colonialism. Wherever imperialists went, accountants and their firms followed. Thus, for instance, British accounting firms "by the beginning of the twentieth century had already set up an empire-wide network of overseas branches and affiliates. In 1902 there were a total of eleven such organisations spread across the continents of Africa, Asia and Australasia [...]. By 1921, the number of these overseas offices had grown to 107, and had further spread to include the North American continent" (Annisette, 2000: 639). This development was strongly supported by British accounting associations who "actively encouraged the migration of their members in order to service the needs of British capital" (Sian, 2006: 303; see also Johnson and Caygill, 1971). And in serving the needs of British capital overseas, UK accountants and their firms did not just sell services around the world; they also shaped the institutional contexts of the colonies in line with their interests and those of the wider imperialist project to which they were party. In particular, they contributed to reproducing UK-based accounting systems around the world and to preventing the emergence of independent indigenous accounting professions (see e.g. Annisette, 2000, 2010; Bakre, 2005, 2006; Sian, 2010).

The emergence of the USA as the world's most dominant power after the Second World War and the rapid internationalisation thereafter of American companies has continued and strengthened this symbiotic relationship between Western accountancy and Western imperialism (Annisette, 2000, 2010; Bakre, 2008; Dywer and Roberts, 2004). In particular, it facilitated the rise of the 'Big Eight' (now 'Big Four') Anglo-American accounting firms in the 1950's and 1960's (Daniels, Thrift and Leyshon, 1989; Stevens, 1981). As American companies (and to a lesser extent British ones) expanded across nations in the second half of the twentieth century in an attempt to increase their scale of capital accumulation, the Big Four followed in their footsteps, offering them auditing - but also increasingly consulting - services wherever they needed them around the world. After a period of expansion into Western Europe (Baskerville and Hay, 2010; Moizer et al., 2004), the Big Four turned their attention to the Middle East (Gallhofer et al., 2011), Eastern Europe and the former communist states of the 
Soviet Union (Cooper, et al., 1998; Mennicken, 2010; Seal, Sucher, and Zelenka, 1996) and, more recently, Asia, especially China (Gillis, 2014). The attractiveness of these "emerging markets" has been considerable and the Big Four "have made every effort to establish branches in [them], in order to support the operation of their multinational clients" (Dedoulis and Caramanis, 2007: 397-98). As a result, the firms have become "massive international operators" (Ferner et al., 1995: 343) and now have offices dotted all around the world, employing 100,000s professionals in hundreds of countries (Baskerville and Hay, 2010; Caramanis, 1999; Cooper, Greenwood, Hinings and Brown, 1998).

In this evolutionary process, the Big Four have, since the 1980s, consistently portrayed themselves as 'transnational' entities, i.e. as organisations that have become detached from their national contexts and evolved into post-national and post-colonial businesses. Evidence of this can be found in the firms' own literature and websites as well as in several studies conducted on the firms since the 1990s. For instance, Cooper et al. (1998) notes how the Big Four (then Big Six) "present themselves increasingly as supranational agents of capitalism that transcend the 'imagined communities' (Anderson, 1991) of nations, national economies and nationalism." Thus, whilst they may have previously been British or American in origin and enmeshed in Western colonialism, they presently claim to be operating as stateless enterprises in a 'borderless world' (Ohmae, 1990) in which core-periphery relations are a thing of the past. However, a closer examination of the firms and their activities reveals a different reality.

\section{Core-periphery relations}

The language of 'globalisation' and 'transnationalism' can easily obfuscate some basic facts about the Big Four. To begin with, the firms have been and continue to be firmly anchored in the USA and the UK. A cursory glance at their websites and annual reviews reveals that their top management teams are mostly composed of staff based in the US and, to a lesser extent, the UK. In this context, it is not surprising that top-level strategic decision-making within the firms is heavily influenced by Anglo-American offices (Barrett et al., 2005; Cooper et al., 1998; Hanlon, 1994). Hanlon (1994), for instance, shows how key strategic decisions such as those relating to international mergers between member firms are generally made by US and, to a lesser extent, UK partners: "because the US partners form a very large minority of the worldwide membership they can, to a large extent, dictate the outcome" (p. 66). Partners from lesser offices such as the Irish on the other hand "make up such a small minority of the international firm that their voice largely goes unheard" (ibid.). Crucially, the strategic emphasis of the Big 
Four has always been, and continues to be, on serving Anglo-American multinationals (as well as multinationals from other core economies through offices based in such contexts) - as noted earlier, serving such clients has been a key reason why the firms have expanded across nations and continue to operate internationally. Thus, in many ways, the Big Four are Western firms serving Western clients around the world rather than 'transnational' organisations operating in a borderless world.

In this capacity, the Big Four do not merely provide some form of 'neutral' set of services on a worldwide basis; they also (re)produce core-periphery relations in the modern world economy. Here, it is crucial to remember that, as argued earlier, multinationals constitute a major agent of the new imperialism. Thus, in serving these businesses, the Big Four are themselves inevitably implicated in the contemporary imperialist project. The accounting literature provides ample evidence on this relationship and, in particular, on the role of the Big Four in opening up new markets and new production, labour and resource capacities and possibilities in the periphery for their multinational clients. For instance, Dwyers and Roberts (2004) explain how the firms' literature is ridden with references to the "new economic order", to their involvement in major "privatization deals" in developing nations, and to their publishing of reports on emerging markets containing "everything necessary to locate desirable buys, assess risks and rewards and negotiate the most favourable deals." The Big Four also play a key role in global financial regulation through their significant influence on standard setting agencies such as the International Accounting Standards Board (Botzem, 2014; Botzem and Quack, 2009) and, in so doing, help in establishing the financial infrastructure that allows Western corporations to enter and exploit developing nations (Annisette, 2000; Bakre, 2008). Annisette (2000: 653) notes how the Anglo-American accountancy internationalisation movement of the 1970's was part and parcel of the new imperialism in that "it served to facilitate a smoother incorporation of overseas economies into the expanding world economy, oriented around the US." Further, the Big Four assist multinationals in designing complex tax avoidance schemes, as a result of which "[d]eveloping countries may be losing around US $\$ 385$ billion of tax revenues each year, dwarfing all the loans, donations and foreign aid put together" (Sikka, 2008: 273).

Thus, the Big Four directly contribute - via the services they provide to multinationals to reproducing the core-periphery hierarchy that resulted from the 'old' imperialism of European colonial powers. What is also interesting is that they appear to be reproducing this 
hierarchy within their own organisational boundaries. For instance, Barrett et al. (2005: 21) explain that, within the firms, "there are core and periphery offices, with the core often reflecting their location in large metropolitan cities, such as London, New York and Tokyo, where most head offices of multinational corporations are located." These core and peripheral offices tend to have different functions: 'core' offices focus on serving Western multinationals and accompany them on their journey to global market dominance whereas 'peripheral' offices concentrate on less significant (from the viewpoint of the core) local clients whilst also acting as intermediaries and a source of 'cheap' labour for the global client projects led by the core. Barrett et al. (2005) show how profits generated from global audit projects are split between core and peripheral offices but not evenly distributed amongst them. Since global client service partners are endowed with a great degree of authority within the firms, being as they are close to the headquarters of multinationals and in charge of prestigious global projects, they are able to attract significantly more profit to their office than those partners operating at the periphery. The latter are then left "at the 'end of the line', picking up the crumbs of revenue and profit permitted by more central partners" (Barrett et al., 2005: 20).

\section{Universalism and exclusion}

Alongside their efforts to facilitate global "free trade" internally and externally, the Big Four have been actively engaged in universalising their Anglo-American mode of professionalism as means of facilitating their cross-national work with multinational clients. As Annisettte (2000: 653) explains, "it was the desire to reduce the complexity of their multinational service which placed these Anglo-American [firms] in the forefront of the movement to reconstitute accountancy as a single world-wide profession with standardised practices and a standardised knowledge base. Unsurprisingly therefore, the products of such standardisation bear a distinct Anglo-American accounting bias" (see also Benson, 1976; Hove, 1990). This work has proceeded on two related fronts - one external and the other internal to the firm.

Externally, the Big Four have, in association with UK/US professional associations, worked to internationalise the Anglo-American accounting model at the level of the profession and, in so doing, gradually displaced, or inhibited the development of, indigenous accounting firms and professions in many countries whilst also shaping them in ways that have excluded segments of the local populations based on ethnic and cultural criteria and in line with AngloAmerican interests (Annisette, 2003; Cooper and Robson, 2006; Dwyer and Roberts, 2004). The accounting literature provides rich insights into how this has been achieved in former 
colonies such as Jamaica (Bakre, 2005, 2006), Kenya (Sian, 2006, 2010), Trinidad \& Tobago (Annisette, 2000), and Syria (Kamla et al., 2006; Kamla, 2007) as well as in small European nations such as Greece (Caramanis, 1999, 2002). In being part of, and exerting considerable influence on, local professional associations, the Big Four have in effect contributed to excluding locals by controlling entry to the profession. As a result, the number of indigenous accountants has remained proportionately small and very few indigenous firms have developed in many parts of the world. Local governments have sought to resist but, as Caramanis (2002: 380) argues, the Big Four "- well positioned within the international economic system - are capable of mobilising almost every powerful international politico-economic actor to overcome the resistance of local players and (weaker) nation states" (see also Arnold, 2005).

Such processes of universalisation/exclusion are also at work within the firms themselves. The definition of professional standards and practices essentially takes place in AngloAmerican offices (Hanlon, 1994). Such materials are then diffused throughout the firms' global networks of offices through various training programmes and socialisation practices (Greenwood et al., 2010). Hanlon (1994) shows how offices based in small economies, while enjoying a degree of autonomy in relation to some business matters (e.g. partner promotion, client management, use of advertising, etc.), are required to adhere to the standards laid down by the US and UK offices. The firms also impose the language of these offices - English - as their global corporate lingua franca. The process not only serves to diffuse Anglo-American standards globally and facilitate cross-national service delivery but also leads to the gradual exclusion of local forms of knowledge and issues of importance to local business communities. For instance, in a study conducted in Syria, Kamla et al. (2012: 1181) highlight "the substantive influence of global accounting firms as employers and trainers of Syrian accountants" and how working for such organisations produces professionals that are more oriented to the AngloAmerican business context than to their own (see also Barrett et al., 2005).

\section{Collaboration and resistance}

Whilst highlighting the imperialist nature of the Big Four, their power should not be overstated; nor does it seem appropriate to see the Anglo-American model - in both its economic and cultural forms - as being merely externally imposed. As is always the case in imperialism, the maintenance of core-periphery relations by the Big Four has been strongly dependent on the collaboration of local professionals. The reality is that these organisations have been very attractive to professionals aspiring to join local accounting and business elites. As Botzem 
(2014: 938) explains, “[t]he Big Four are excellent training grounds as they facilitate the gathering of experiences, soft skills and "technical" knowledge that are difficult to acquire elsewhere. Working for a big firm delivers practical insights, providing individuals with high social status" (see also Hanlon, 1994; Ramirez, 2010). Thus, locals to some extent contribute to their own subjugation. This is of course in the context of a system that has already largely established itself as a norm in many parts of the world through the Anglo-American accountancy internationalisation movement of the 1970's which, in many countries, contributed to forming "an indigenous class of accounting manpower schooled in a manner suited to the needs of international [Anglo-American] capital" (Annisette, 2000: 653). Joining and receiving training from the Big Four today in effect continues this process of local cooptation. The process is reinforced through the encouragement of locals to visit the US/UK offices at some point in the careers as a means of further socialisation (Hanlon, 1994, 1999).

Yet, such collaboration is, paradoxically, accompanied by various structural and cultural contradictions and resistances that, taken together, render the Big Four's imperialist project fragile. On a structural level, the firms remain federations of legally independent national partnerships linked through umbrella organisations - labelled 'world firms' or 'international offices' - and this puts a break on efforts to control, use and exploit the resources of overseas offices towards to the provision of cross-national services to Anglo-American multinationals. In his recent study of the Big Four, Gillis (2014: 48) explains the problem neatly: "The focal point for capital investment in the Big Four is the national firm. Partners are admitted to a national firm, rather than the global firm, and contribute their capital to that firm. The firms have retained this historic relic because of its efficacy in "ring fencing" exposure to litigation. When Arthur Andersen failed in 2002, only the United States firm failed outright, despite Arthur Andersen being considered the most integrated of the Big Five. [...] The national firm structure creates significant barriers to seamless global operations for the Big Four firms. Because profits are determined and distributed primarily based on national results, the legal structure has the potential to create tensions between member firms. The allocation of fees on global audit clients among the various firms participating in the audit is a continual source of conflict" (see also Barrett et al., 2005). The firms are thus still characterised by a nation-centric internal world, albeit one dominated by Anglo-American offices and, in this context, local elites have a degree of power to limit the extent to which the labour they control is leveraged and exploited by the core. 
The Big Four's imperialist project is also inhibited by cultural centrifugal forces. Although the firms' offices voluntarily came together into global networks to practice under common (Anglo-American) professional standards, those based outside the Anglosphere do not seem to always be working to such standards - despite their attraction to such standards, as noted above. The study of Barrett et al. (2005) is particularly useful here. The authors show how, in one of the Big Four (then Big Six) they researched, the North American offices perceived a European office as "incompetent" (Barrett et al., 2005: 18). This is exacerbated by processes of local appropriation and adaption. Barrett et al.'s (2005) detailed study of one global audit project involving accountants attached to offices in Canada, Europe and the USA found that although the firm utilized 'standardized' work procedures, "the coherence and effectiveness of the audit [was] an ongoing, but always problematic achievement" (p. 3). The firm's 'standardized' procedures were taken up quite variably, depending on national characteristics, partner ambitions for visibility and specifics of the local business being audited. Thus, in spite of the relevant parties sharing an interest in the universalisation of the Anglo-American model, the possibility accomplishing this in practice is continually undermined by perceptions of difference and uneven quality as well as processes of local transformation.

\section{Transnationalism in context: GPSFs and the new imperialism}

The case of the Big Four discussed above reveals that the international expansion and associated international strategies and organisational efforts of GPSFs have been bound up with Western imperialism - past and present. Several insights can be derived from this in relation to ongoing discussions about the societal role and impact of GPSFs at the global level.

Firstly, the analysis shows that GPSFs contribute to (re)producing core-periphery relations in the world economy. Whilst presenting themselves as 'transnational' organisations, the firms are in fact controlled by offices based in core economies (mostly the US, with the UK units also occupying an important hierarchical position given their cultural and linguistic proximity to the former and their important historical and present role in professionalization projects around the world). The firms remain built around this 'core' set of offices, which in effect 'own' relationships with multinational clients - themselves originating and headquartered in core economies. The remaining offices (most probably to varying degrees depending on their position in the world hierarchy of nations) occupy 'peripheral' positions, serving as local advisers and bridges into new markets in the 'developing' world as well as potentially a source of 'cheap' labour. Thus, GPSFs mirror the international division of labour 
that was established in colonial times and help to extend it into the $21^{\text {st }}$ century by growing on the back of, and controlling relationships with, Western multinationals.

Secondly, core-periphery relations within GPSFs are reinforced by significant universalistic efforts on the part of the firm's core offices. Such offices strongly depend on the periphery for their international expansionism and thus work to universalise their particular economic interests - serving multinational clients around the world - through the abstract language of 'globalisation' and 'transnationalism'. Thus, Anglo-American multinational clients become 'global' clients, their Anglo-American service providers become 'global' firms, and serving the former becomes a question 'global' strategy affecting all members of the organisation equally. Related to this, core offices also work to universalise their particular model of professional practice, for without it the task of serving 'global' clients becomes very challenging. They seek to extend it to the whole firm by presenting it as a norm, a universal so as to secure global commitment to it. Thus, Anglo-American standards are renamed as 'global' standards and then diffused throughout the organisation through 'global' policies and training programmes. This is reinforced by external efforts to embed the Anglo-American model in local professional jurisdictions via the work of international standard setting agencies. And in so doing, GPSFs do not just reproduce Anglo-American professional standards at the periphery; they also produce subjects - local elites - that are subordinated to and aligned with Anglo-American capital. These actors are crucial to the system in that the new imperialism operates without direct colonial rule and requires local agents to help in opening new markets, in accessing low-cost labour and in performing the local managerial functions that provide dayto-day order in the global networks of the firms.

Yet, thirdly, imperial efforts by GPSFs are continually frustrated by local resistances. Whilst the firms are able to universalise Anglo-American standards, their local collaborators retain a degree of freedom and, through 'mimicry' (Bhabha, 1994), produce homogenization and difference, thereby accepting and yet resisting domination, simultaneously. Power is inscribed in 'global' standards but these materials require interpretation, and this implies scope for local agency, appropriation and adaptation. Thus, 'global' standards are not necessarily always reproduced as expected. They are presented as universals as a means of extending the reach of Anglo-American localisms across the globe, marginalising in the process other local conceptions as 'backward' localisms, but interpretation to some extent reverses that power - it takes hold of the 'global' standards and transforms them in ways that produce heterogeneity 
just as standardization seeks to eradicate it; it continually localises 'global' standards and thereby perpetually threatens their very raison d'être.

What are we to conclude from these insights? That the globalisation of professional service firms is intimately related to Western imperialism, I contend. Why then is this link not systematically explored in professions-focused MOS studies? It is difficult to say, but it may perhaps be due to the fact that such studies are mostly guided by a conceptual lens institutional theory - that is generally reticent to engage with issues of power or rather as, Munir (2014: 2) puts it, "problematic uses of power". But this is no longer tenable in the context of the "growing and deepening global inequalities that have emerged over several decades of globalizing capitalist development" (Petras and Veltmeyer, 2007: 21) and which multinationals, in association with international organisations such as the IMF and the World Bank, have directly contributed to. The case of the Big Four shows that GPSFs have been deeply implicated in this process and thus time has come to bring imperialism into the discussion.

We have much to learn from our critical accounting colleagues in this regard. One of the strengths of their work is that it is willing to name imperialism and chart imperial processes in the global expansion of the professions. They have taken in some of the advances achieved in specialist studies of imperialism and in postcolonial theory; they have recognized that imperialism is at the core of their object of analysis. My point is that the same should be achieved in the emerging field of institutionalist research on GPSFs and the professions more generally. This would help in catching up with the field of accounting but also the wider social sciences where imperialism has returned as a key analytical frame and topic of discussion in the last decade or so (see e.g. Harvey, 2003; Pieterse, 2004; Saccarelli and Varadarajan, 2015). Organising empirics around a narrative of imperialism allows us to bring power relations to the forefront. And this is crucial for a better understanding of GPSFs because, ultimately, these entities are not 'neutral' organisational systems - they represent a change in, and re-articulation of power relations at the global level. A narrative of imperialism would also bring the relevant actors more clearly into view, making it clearer that globalisation is mostly a story of core actors expanding beyond their geographic borders, serving Western multinational clients abroad, opening new markets in the 'developing' world and, ultimately, consolidating market and political power on a worldwide scale. It would also make it clear that globalisation is also a story of peripheral actors cooperating with, or otherwise resisting, domination. 
In this paper, I have made a modest contribution to moving the discussion towards a narrative of imperialism but much remains to be done. Clearly, much more research is required on the specific mechanisms of imperialism inside GPSFs, and also externally at the interface between these organisations and the markets which they open up and seek to 'conquer'. It seems also crucial to explore in greater depth local processes of collaboration and resistance at the periphery - understood here as not just former colonies but also small nations in the West and elsewhere. For imperialism is never just externally imposed and also rarely proceeds without some degree of resistance, conscious or not. Much research is also needed on what in practice are likely to be varieties of domination and varieties of responses to it. The periphery is not an "undifferentiated fringe" (Chua and Poullaos, 2002: 412) and, equally, the 'core' is by no means a homogeneous space - these differences can be expected to have an influence on how the dynamics discussed in this paper work themselves out in practice. Finally, and related to this point, research is required on how the on-going shift in the global balance of power towards non-Western nations (e.g. BRICs) may be affecting core-periphery relations in the professional services sector.

\section{Concluding remarks}

This paper began with a brief overview of the growing body of institutionalist research on GPSFs and with the argument that global relations of domination and inequality have been given insufficient attention in this work. I have sought to begin to address this problem by, first, positing that GPSFs cannot be divorced from imperialism and, second, illustrating this relationship through an analysis of relevant research conducted in the specialist field of accounting. Broadly speaking, I have argued that GPSFs, in expanding across nations to serve multinational clients and, as a consequence, in attempting to leverage resources and control professional standards on a worldwide basis, are (re)producing the core-periphery hierarchy that was produced by the European colonial project. In this sense, the globalisation of professional service firms is not just contributing to building a transnational field for professional services, it is also serving to reinforce long-standing West/Rest relations of domination and subordination. Perhaps the more important contribution of this paper, however, is that it formally connects professions-focused MOS research with studies of imperialism in the field of critical accounting and the social sciences more broadly. The former has been largely oblivious to processes of imperialism, but this is no longer tenable given the major impact that imperialism has had, and continues to have, on the world economy. 


\section{References}

Aharoni, Y. (1996), “The organization of global service MNEs", International Studies of Management and Organization, 26, 6-23.

Amin, S. (1976), L 'impérialisme et le développement inégal, Les Éditions de Minuit

Annisette M. (2000), "Imperialism and the professions: the education and certification of accountants in Trinidad and Tobago", Accounting Organisations and Society, 25:631-59.

Annisette, M. (2003), "The colour of accountancy: Examining the silence of race in a professionalization project", Accounting, Organizations and Society, 28(7/8), 639-674.

Annisette M. (2010), "Maintaining empire: the practice link in Trinidad and Tobago", in: Poullaos M, Sian M, (Eds), Accountancy and empire: the British legacy of professional organisation. London: Routledge; p. 168-91.

Arnold, P. J. (2005), “Disciplining Domestic Regulation: The World Trade Organization and the Market for Professional Services", Accounting, Organizations and Society, 30: 299-330.

Arnold, P. J. and Sikka, P. (2001). Globalization and the state-profession relationship: The case of the Bank of Credit and Commerce International. Accounting, Organizations and Society, 26(6), 475-499.

Bakre, O. M. (2005), "First attempt at localising imperial accountancy: the case of the Institute of Chartered Accountants of Jamaica (1950s-1970s)", Critical Perspectives on Accounting vol. 16(8), 995-1018.

Bakre, O. M. (2006), "Second attempt to localise imperial accountancy: the case of the Institute of Chartered Accountants of Jamaica (1970s-1980s)", Critical Perspectives on Accounting, $17: 1-28$.

Bakre, O. M. (2008), "Financial reporting as technology that supports and sustains imperial expansion and control in the colonial and post-colonial globalisation: the case of the Jamaican economy", Critical Perspectives on Accounting, pp. 431-486.

Barrett, M., Cooper, D. and Jamal, K. (2005), "Globalization and the coordinating of work in multinational audits", Accounting, Organizations and Society, 30(1): 1-24.

Baskerville, R., \& Hay, D. (2010), “The impact of globalization on professional accounting firms: Evidence from New Zealand”, Accounting History, 15(3), 285-308.

Bhabha, H. K. (1994). The location of culture. London: Routledge.

Benson, H. (1976), “The story of international accounting standards”, Accountancy, 34-39.

Botzem, S. (2014), “Transnational standard setting in accounting”, Accounting, Auditing \& Accountability Journal, 27(6), pp. 933-955. 
Botzem, S. and Quack, S. (2009), “(No) limits to Anglo-American accounting? Reconstructing the history of the international accounting standards committee: A review article", Accounting, Organizations and Society, 34(8): 988-998.

Boussebaa, M. (2009), "Struggling to organize across national borders: The case of global resource management in professional Service Firms”, Human Relations, 62(6): 829-850.

Boussebaa, M. (2015), "Control in the multinational enterprise: The polycentric case of global professional service firms", Journal of World Business, 50(4).

Boussebaa, M. and Morgan, G. (2008), "Managing talent across borders: the challenges faced by an international retail group", Critical Perspectives on International Business, 4: 25-41.

Boussebaa, M. and Morgan, G. (2014), "Pushing the frontiers of critical international business studies: the multinational as a neo-imperial space", Critical Perspectives on International Business, 10(1-2): 96-106.

Boussebaa, M. and Morgan, G. (2015), "Internationalization of professional service firms: drivers, forms and outcomes", in L. Empson, D. Muzio, J. Broschak and B. Hinings (Eds), Oxford Handbook of Professional Service Firms. Oxford: Oxford University Press.

Boussebaa, M., Morgan, G. and Sturdy, A. (2012), "Constructing global firms? National, transnational and neocolonial effects in international management consultancies", Organization Studies, 33(4): 465-486.

Boussebaa, M., Sinha, S., and Gabriel, Y. (2014a), "Englishization in offshore call centers: A postcolonial perspective”, Journal of International Business Studies, 45(9): 1152-1169.

Boussebaa, M., Sturdy, A. and Morgan, G. (2014b), "Learning from the world? Horizontal knowledge flows and geopolitics in international consulting firms", International Journal of Human Resource Management 25(9): 1227-1242.

Brock, D., Leblebici, H. and Muzio, D. (2014), "Understanding professionals and their workplaces: The mission of the Journal of Professions and Organization", Journal of Professions and Organization, 1(1), pp. 1-15.

Caramanis, C. (1999), "International accounting firms versus indigenous auditors: Intraprofessional conflict in the Greek auditing profession, 1990-1993", Critical Perspectives on Accounting, 10(2), 153-196.

Caramanis, C.V. (2002), "The Interplay between Professional Groups, the State and Supranational Agents: Pax Americana in the Age of 'Globalisation'”, Accounting, Organizations and Society, 27(4-5), pp.379-408.

Chase-Dunn, C. (1998). Global Formation: Structures of the World-Economy (updated edition). Oxford: Rowman \& Littlefield Publishers. 
Chua, W. and Poullaos, C. (2002). The Empire strikes back? An exploration of centreperiphery interaction between ICAEW and accounting associations in the self-governing colonies of Australia, Canada and South Africa, 1880-1907. Accounting, Organisations and Society, 27(4/5), 409-445.

Cooper, D. J., Greenwood, R., Hinings, B. and Brown, J. (1998), "Globalization and nationalism in a multinational accounting firm: The case of opening new markets in Eastern Europe”, Accounting, Organizations and Society, 23: 531-548.

Cooper, D., Greenwood, R., Hinings, B. and Brown, J.L. (1998), "Globalization and nationalism in a multinational accounting firm: the case of opening new markets in Eastern Europe”, Accounting, Organizations and Society, 23(5-6): 531-548.

Cooper, D. J. and Robson, K. (2006), “Accounting, professions and regulation: Locating the sites of professionalization", Accounting, Organizations and Society, 31(4-5), 415-444.

Daniels, P. W. Thrift, N. J. and Leyshon, A. (1989), "Internationalisation of professional producer services: Accountancy conglomerates", in P. Enderwick (Ed.), Multinational service firms (pp. 79-106). London: Routledge.

Dezalay, Y. and Garth, B. (2002), The Internationalization of Palace Wars: Lawyers, Economists and the Contest to Transform Latin American States. Chicago, IL: University of Chicago Press.

Dezalay, Y. and Garth, B. (2008), "Law, Lawyers, and Empire", in M. Grossberg and C. Tomlins (Eds), The Cambridge History of Law in America (pp. 718-59). Cambridge: Cambridge University Press.

Dezalay, Y. and Garth, B. (2010), Asian Legal Revivals: Lawyers in the Shadow of Empire. Chicago. IL: University of Chicago Press.

Dwyer, P. D. and Roberts, R. W. (2004), “The contemporary gender agenda of the US public accounting profession: Embracing feminism or maintaining empire?", Critical Perspectives on Accounting, 15(1): 159-77.

Empson, L., Muzio, D., Broschak, J. and Hinings, B. (2015), Oxford Handbook of Professional Service Firms, Oxford: Oxford University Press.

Faulconbridge, J. and Muzio, D. (2012), "The rescaling of the professions: towards a transnational sociology of the professions", International Sociology, 27: 109-125.

Faulconbridge, J. and Muzio, D. (2015), "Global professional service firms and the challenge of institutional complexity: 'field relocation' as a response strategy”, Journal of Management Studies, 65. In Press. 
Fenton, E. and Pettigrew, A. M. (2003), "Complementary: change towards Global Integration in Four Professional Service Organizations", in Pettigrew et al. (Eds) Innovative Forms of Organizing. London: Sage.

Ferner, A, Edwards, P., Sisson, K (1995), “Coming unstuck? In search of the 'Corporate glue' in an international professional service firm",' Human Resource Management, 34(3): 34361.

Ferner, A., Quintanilla, J. and Varul, M. (2001), "Country-of-origin effects, host-country effects, and the management of HR in multinationals: German companies in Britain and Spain”, Journal of World Business, 36(2): 107-127.

Fortune Magazine, A New Perspective on the Corporate World. CNN Money, Fortune Magazine. Retrieved 19 May 2014.

Frenkel, M. (2008), “The multinational corporation as a third space: Rethinking international management discourse on knowledge transfer through Homi Bhabha", Academy of Management Review, 33(4): 924-942.

Frobel, F., Heinrichs, J. and Kreye, O. (1980), The New International Division of Labour. Cambridge: Cambridge University Press.

Gallhofer, S., Haslam, J., and Kamla, R. (2011), "The accountancy profession and the ambiguities of globalisation in a post-colonial, Middle Eastern and Islamic context: Perceptions of accountants in Syria”, Critical Perspectives on Accounting, 22(4), 376-395.

Gillis, P. (2014), The Big Four and the Development of the Accounting Profession in China. London: Emerald.

Greenwood, R., Morris, T., Fairclough, S. and Boussebaa, M. (2010), “The organizational design of transnational professional service firms", Organizational Dynamics, 39: 173-183.

Halliday, T. C., and Carruthers, B. G. (2009), Bankrupt: Global Lawmaking and Systemic Financial Crisis. Stanford, CA: Stanford University Press.

Hanlon, G. (1994), The commercialisation of accountancy: Flexible accumulation and the transformation of the service class, London: Macmillan.

Hanlon, G. (1999), "International professional labour markets and the narratives of accountants", Critical Perspectives on Accounting, 10(2), pp.199-221.

Harvey, D. (2003), The new imperialism. Oxford: Oxford University Press.

Hove, M. (1990), "The Anglo-American influence on international accounting standards", in R.S.O. Wallace, J. Samuels, \& R. Briston, Research in Third World accounting, London: JAI Press. 
Jack, G., Westwood, R., Srinivas, N. and Sardar, Z. (2011), "Deepening, broadening and reasserting a postcolonial interrogative space in organization studies", Organization, 18(3): $1-28$.

Johnson, T. J. (1973), "Imperialism and the professions", in P. Halmos (Ed.), Professionalization and social change (pp. 281-309), Cambridge: Cambridge University Press.

Johnson, T. J. and Caygill, M. (1971), "The development of accounting links in the Commonwealth", Accounting and Business Research, 155-173.

Kamla, R., Gallhofer, S. \& Haslam, J. (2012), “Understanding Syrian accountants’ perceptions of, and attitudes towards, social accounting”, Accounting, Auditing \& Accountability Journal, 25(7), pp. 1170-1205.

Malhotra, N. and Morris, T. (2009), "Heterogeneity in professional service firms", Journal of Management Studies, 46: 895-922.

McKenna, C. D. (2006). The world's newest profession. Management consulting in the twentieth century. Cambridge: Cambridge University Press.

Mennicken, A. (2010), "From inspection to auditing: Audit and markets as linked ecologies", Accounting, Organizations and Society, 35(3), 334-359.

Moizer, P., Benau, M., Humphrey, C. and Martinez, A. (2004). The corporate image of auditors in a developing audit market within the EU: the case of Spain. European Accounting Review, 13(3), 561-582.

Morgan, G. (2006), “Transnational actors, transnational institutions, transnational spaces: the role of law firms in the internationalization of competition regulation", in Djelic, M.-L. and Sahlin-Andersson, K. (Eds), Transnational governance. Institutional dynamics of regulation, Cambridge: Cambridge University Press, 139-160.

Morgan, G. and Quack, S. (2005), "Institutional legacies and firm dynamics: the growth and internationalization of UK and German law firms", Organization Studies, 26(12): 17651785.

Morgan, G. and Quack, S. (2006), "The internationalization of professional service firms: Global convergence, national path-dependency or cross-border hybridization?", in Greenwood, R. and Suddaby, R. (Eds) Research in the Sociology of Organizations Volume 24: Professional Service Firms. Oxford: JAI Press, pp. 403-431.

Morgan, G., Sturdy, A. and Quack, S. (2006), “The globalization of management consultancy firms: constraints and limitations", in M. Miozzo and D. Grimshaw (eds), Knowledge 
Intensive Business Services and Changing Organizational Forms, Cheltenham: Edward Elgar, 236-264.

Munir, K. (2014), “A loss of power in institutional theory”, Journal of Management Inquiry.

Muzio, D. \& Faulconbridge, J. (2013), “The global professional service firm: ‘one firm' models versus (Italian) distant institutionalized practices”, Organization Studies, 34(7): 897-925.

Ohmae, K. (1990), The borderless world: Power and strategy in the interlinked economy, London: HarperCollins.

Özkazanç-Pan, B. (2008), "International management research meets "the rest of the world", Academy of Management Review, 33, 4, 964-974.

Petras and Veltmeyer (2007), Multinationals on Trial.

Pieterse, N. (2004), Globalization of Empire?

Post, H. A. (1996), "Internationalization and professionalization in accounting services: The cases of BDO Binder and BDO CampsObers", International Studies of Management \& Organization, 26(2), 80-103.

Poulantzas, N. (1976), The crisis of the dictatorships, London: New Left Books.

Prasad, A. (2003), Postcolonial theory and organizational analysis. New York: Palgrave.

Ramirez, C. (2010), 'Promoting transnational professionalism: Forays of the 'Big Firm' accounting community into France", in Djelic, M.-L. and Quack, S. (Eds), Transnational Communities: Shaping Global Economic Governance, Cambridge University Press, Cambridge, pp. 174-195.

Said, E. (1978). Orientalism.

Said, E. (1993). Culture and imperialism.

Sassen, S. (2001),

Seal, W., Sucher, P., \& Zelenka, I. (1996), "Post-socialist transition and the development of an accountancy profession in the Czech Republic", Critical Perspectives on Accounting, 7(4), 485-508.

Sikka, (2008), "Enterprise culture and accountancy firms: new masters of the universe", Accounting, Auditing \& Accountability Journal, Vol. 21, 2, pp. 268-295.

Smets, M., Morris, T. and Greenwood, R. (2012), "From practice to field: multi-level model of practice-driven institutional change", Academy of Management Journal, 55(4), pp. 877904.

Spence, C., Dambrin, C., Carter, C., Husillos, J. and Archel, P. (in press), “Global ends, local means: cross-national homogeneity in professional service firms", Human Relations, published online, 16 October 2014. 
Suddaby, R., Cooper, D. J. and Greenwood, R. (2007), "Transnational regulation of professional services: governance dynamics of field level organizational change", Accounting, Organizations and Society, 32, 4-5, pp.333-362.

Wallerstein, E. (2011), The Second Era of Great Expansion of the Capitalist World Economy, 1730s-1840s. Berkeley: University of California Press. 